\title{
Antibodies to Rickettsia rickettsi, Rickettsia typhi, Coxiella burnetii, Bartonella henselae, Bartonella quintana, and Enrlichia chaffeensis among healthy population in Minas Gerais, Brazil
}

\author{
Paulo Sérgio Gonçalves da Costa/ ${ }^{+}$, Marcos Emilio Brigatte* , Dirceu Bartolomeu Greco
}

Curso de Pós-graduação em Medicina Tropical, Faculdade de Medicina, Universidade Federal de Minas Gerais, Belo Horizonte, MG, Brasil *Hospital Monte Sinai Juiz de Fora, Rua Delfim Moreira 181-902, 36010-570 Juiz de Fora, MG, Brasil

Rickettsial diseases except those belonging to spotted fever group rickettsioses are poorly studied in South America particularly in Brazil where few epidemiological reports have been published. We describe a serosurvey for Rickettsia rickettsii, R. typhi, Coxiella burnetii, Bartonella henselae, B. quintana, and Ehrlichia chaffeensis in 437 healthy people from a Brazilian rural community. The serum samples were tested by indirected micro-immunoflourescence technique and a cutoff titer of 1:64 was used. The seroprevalence rates for R. rickettsii, R. typhi, C. burnetii, B. henselae, B. quintana, and $\mathrm{E}$. chaffeensis were respectively 1.6\% (7 samples); $1.1 \%$ (5 samples); 3.9\% (17 samples); $13.7 \%$ (60 samples); 12.8\% (56 samples), and 10.5\% (46 samples). Frequent multiple/cross-reactivity was observed in this study. Age over 40 years old, urban profession, and rural residence were significantly associated with some but not all infections rate. Low seropositivity rates for $\mathrm{R}$. rickettsii, R. typhi, and $\mathrm{C}$. burnetii contrasted with higher rates of seropositivity for $\mathrm{B}$. quintana, B. henselae, and $\mathrm{E}$. chaffeensis. These results show that all tested rickettsial species or antigenically closely related possible exist in this particular region.

Key words: Bartonella - Rickettsia - Coxiella - Ehrlichia - seroprevalence - Brazil

Rickettsial agents are important emerging and reemerging infectious diseases worldwide (Raoult \& Roux 1997, Parola \& Raoult 2001, Paddock \& Childs 2003) and scant information on such conditions can be found either in Brazil or South America (WHO 1993, Rozental et al. 2002, Walker 2004a). Until recently the rickettsiales order comprised the genus Rickettsia, Coxiella, Bartonella, Orientia, Anaplasma, and Ehrlichia (Raoult \& Roux 1997) and despite of the resulting withdraw of some of them from this order especially due to $16 \mathrm{~S}$ rRNA studies, they all can be functionally considered rickettsial agents (Raoult \& Roux 1997, Walker 2004b).

Most of the available publications of Brazilian rickettsial infections have focused on spotted fever group rickettsioses especially $R$. rickettsii infections (Lemos et al. 1994, 2001, Del Guercio et al. 1997, Rozental et al. 2002, Galvão et al. 2003). This issue has been extensively reviewed recently by Galvão (2004). Despite of the fact that new rickettsial agents have been described more recently in Brazil (Oliveira et al. 2002), the whole scenario of rickettsial infections still have black holes reinforcing the nonexistence concept for such infections in this part of the world.

The Piau county as well as the southern part of the state of Minas Gerais had been considered free of any rickettsial diseases until 1994 when a family cluster of Brazilian spotted fever was reported (Hallack et al. 1996). Thereafter reports of Brazilian spotted fever have been

${ }^{+}$Corresponding author. E-mail: psgcosta@powerline.com.br Received 20 July 2005

Accepted 7 December 2005 increasing in the Piau county and neighborgwoods (Costa et al. 2002).

Given these above mentioned facts and the much-appropriated local ecologic conditions for rickettsial infections we choose this particular region for studying the seroprevalence rates for $R$. typhi, C. burnetii, B. henselae, $B$. quintana, and E. chaffeensis as well as $R$. rickettsii infections among healthy individuals from a Brazilian rural community.

\section{MATERIALS AND METHODS}

Serum samples from 437 healthy individuals of both sexes aged from 5 to 92 years old, living in the county of Piau, state of Minas Gerais, Brazil were tested for the presence of $R$. rickettsii, $R$. typhi, $C$. burnetii phase I and phase II, B. henselae, B. quintana, and E. chaffeensis IgG and IgM antibodies. This county (Fig. 1), located at latitude $21^{\circ} 30$ ' $34^{\prime \prime} \mathrm{S}$ and longitude $43^{\circ} 19^{\prime} 25^{\prime}$ 'W, has 3008 inhabitants, $58 \%$ of them living in the small village and the remainders scattered throughout the county, mostly in small farms. The local economics is somehow linked to cattle farming and the entire population has continuous contact with several domestic animals. Tick attack history is widespread affecting roughly $100 \%$ of the population. From March to April 2001, health officials offered the community yellow fever vaccination set in a single health unit and all persons that showed up and who signed an informed consent had blood samples taken for serological tests and responded a structured questionnaire. All these people were local residents and no one reported the previous diagnosis of any rickettsial disease. There are no reported endemic or epidemic infectious diseases in the Piau county. Local health officials and the institutional ethical committee approved the study. Sample size was calculated considering the seroprevalence rate rang- 


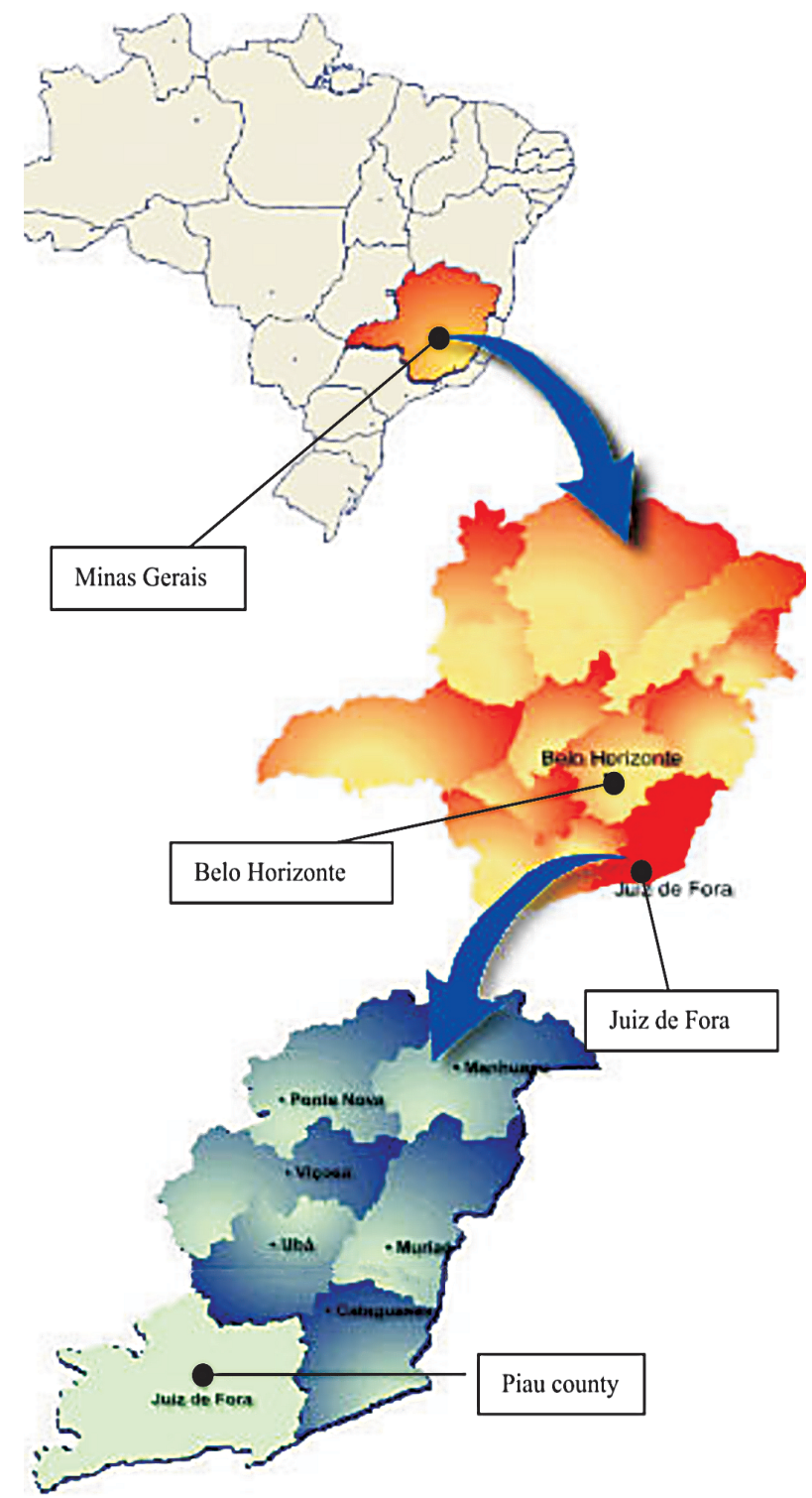

Fig 1: geographic location of the Piau county in Minas Gerais, Brazil.

ing from 2 to $9 \%$ respectively to the less and to the more frequent agent with a standard error of $5 \%$ and CI of $95 \%$. Statistical analysis to compare the frequencies of qualitative data were done by Chi square and Fisher exact test and the difference was considered significant when $p<$ 0.05 .

Serological tests were performed by the microimmunofluorescence technique (IFA) on "in door" slides as described elsewhere (Philip et al. 1976) using C. burnetii (Nine Mile strain-yolk sac hens' egg) phase I and phase II antigens, $R$. typhi (Wilmington strain-yolk sac hens' egg), $R$. rickettsii (Sheila Smith strain-yolk sac hens' egg), $B$. henselae (Houston strain-E6 Vero cells), B. quintana (isolate OK-90-268-E6 Vero cells), and E. chaffeensis (Arkansas strain-DH-82 canine cells). Viral and Rickettsial Branch of CDC Atlanta, US provided antigens and control sera. Fluorescein-conjugated goat anti-human IgG (BioMérieux) obtained commercially was used for antibody detection. Slides readings were performed blindly and a fluorescence of at least 2+ was required for positivity. All sera were initially screened at the dilution of 1:64 considered as cutoff value and were subsequently titered to the end point. Multiple/cross-reactivity rate was calculated dividing the number of positive samples for one agent by the number of positive tests for each other agent from the same samples.

\section{RESULTS}

The seropositivity rate for $R$. rickettsii was $1.6 \%$ (7 positive samples), for $R$. typhi $1.1 \%$ (5 positive samples), for $C$. burnetii $3.9 \%$ (17 positive samples), for $B$. henselae $13.7 \%$ (60 positive samples), for $B$. quintana $12.8 \%$ (56 positive samples), and for E. chaffeensis $10.5 \%$ (46 positive samples). These data are shown in Fig. 2.

Overall, 127 samples corresponding to $29.1 \%$ were reactive to at least one tested agent.

There were no gender differences in seroprevalence. Age over 40 years old was associated with more seropositivity for $R$. rickettsii, C. burnetii phase I, B. henselae, $B$. quintana, and E. chaffeensis but these last two with no statistical significance. E. chaffeensis infection rate was higher among people living in farms than in those living in the village $(p<0.05)$. Rural profession was associated with less seropositivity for $R$. rickettsii than non-rural ones $(p<0.05)$.

Slaughtering, milking, cattle contact, and horse contact were not associated with higher seroprevalence rate to any tested agent.

When the cutoff value of 1:128 was used the overall seroprevalence rate dropped substantially for $R$. rickettsii, $R$. typhi, and $C$. burnetii but still remained noteworthy for Bartonella spp. and E. chaffeensis (Fig. 2). When just one-agent reactive samples were considered ("without multiple/cross-reactivity" - WMCR rate) the numbers remained very close to those from 1:64 cutoff (Fig. 2).

Multiple reactivity or cross-reactivity with other rickettsial antigens (Table) was frequently observed especially between closely related antigens such as $B$. henselae and $B$. quintana. Expressive multiple or cross-reactivity between $R$. typhi and $R$. rickettsii; E. chaffeensis and Bartonella spp.; Bartonella spp. and E. chaffeensis; and $R$. rickettsii and $R$. typhi were also observed.

\section{DISCUSSION}

This serological survey demonstrated the presence of antibodies to all rickettsial species tested in the health population from the Piau county. Taken together, the tested agents are representative of the main human pathogenic rickettsial antigenic groups (Raoult \& Roux 1997).

Except for the $R$. rickettsii (Lemos et al. 1994, 2001, Del Guercio et al. 1997, Rozental et al. 2002, Galvão et al. 2004) seroepidemiologic data on rickettsial infections is missing in Brazil although null seroprevalence for $R$. typhi and $E$. chaffeensis infections has been reported in one recent study by Galvão et al. (2002). This same author however, previously reported in his $\mathrm{PhD}$ thesis, the presence of antibodies for $R$. typhi in $3 \%$ of humans from Caratinga, state of Minas Gerais, Brazil (Galvão 1996). 
As compared with other Brazilian seroprevalence studies the rate found here for $R$. rickettsii was low. Lemos et al. (1994, 2001), Del Guercio et al. (1997), and Galvão et al. (2002) found respectively $7.14,4.2,5.3$, and $10.1 \%$ seroprevalence rates in different serosurveys. Despite this low seroprevalence rate, spotted fever group rickettsioses have been increasing in the studied region with an incidence of over 0.5/100,000 inhabitants-year (Costa 2004) compatible with the ongoing epidemic expansion recently reported from some Brazilian southeast regions (Rozental et al. 2002, Galvão et al. 2003).

R. typhi infections in Brazil have been reported in the past including with agent isolation from at least one human case (Travassos et al. 1949), but recent reports of such infection are scarce (Silveira \& Maestrini 1985, da Silva \& Papaiordaou 2001). However, Brazil is considered

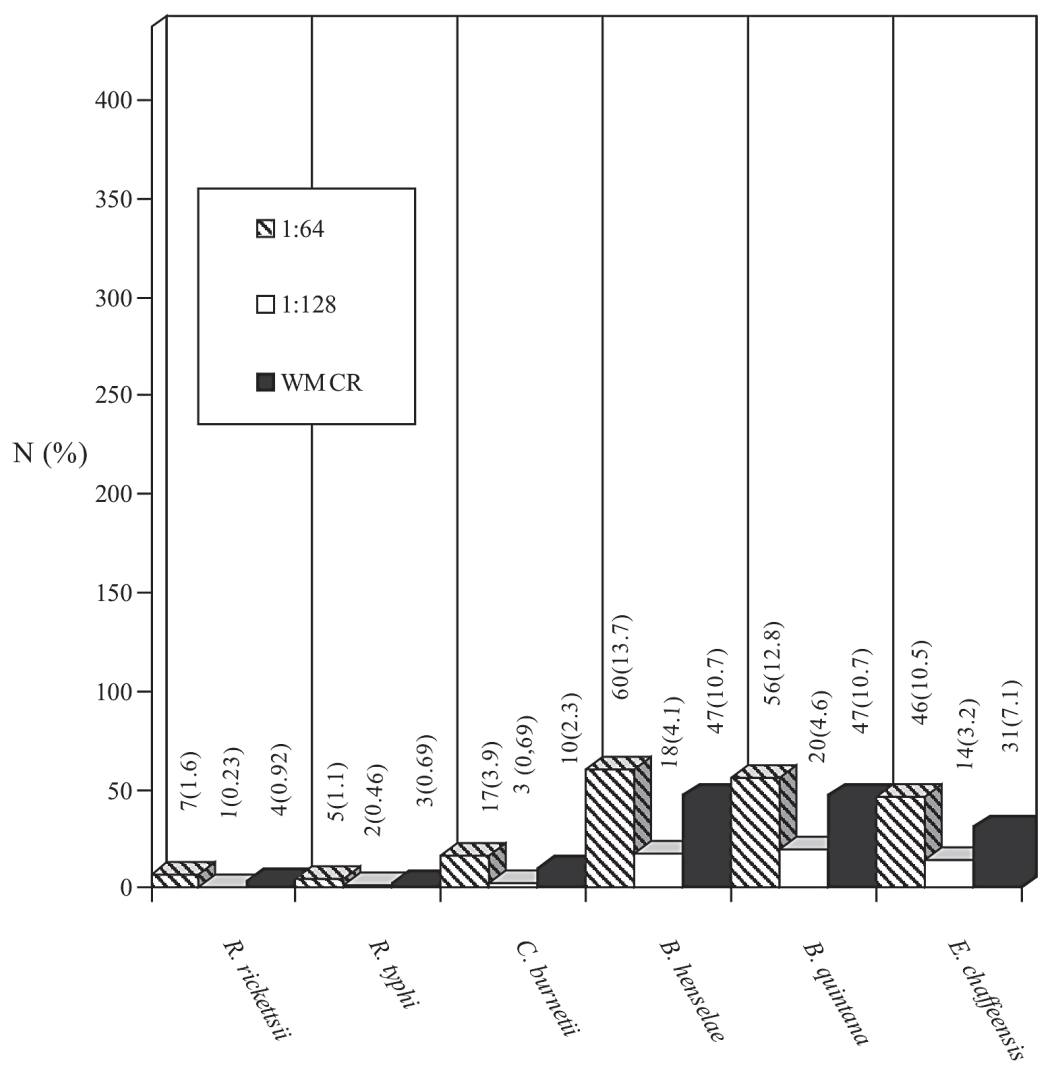

Fig. 2: number of positive samples and seropositivity rates (\%) for Rickettsia rickettsii, R. typhi, Coxiella burnetii, Bartonella henselae, B. quintana, and Ehrlichia chaffeensis in the Piau county at 1:64 cutoff; 1:128 cutoff and "without-multiple/cross-reactivity" - WMCR rate.

TABLE

Frequency (number and rate) of multiple/cross-reactive samples for several rickettsial agents among seropositive individuals from Piau, MG (1:64)

\begin{tabular}{|c|c|c|c|c|c|c|}
\hline Rickettsial agent & 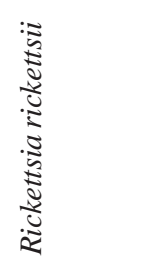 & 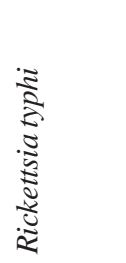 & 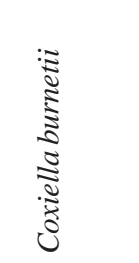 & 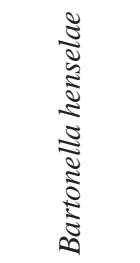 & 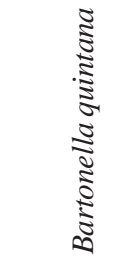 & 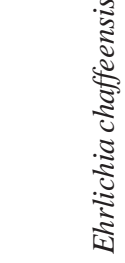 \\
\hline & $\mathrm{N}(\%)$ & $\mathrm{N}(\%)$ & $\mathrm{N}(\%)$ & $\mathrm{N}(\%)$ & $\mathrm{N}(\%)$ & $\mathrm{N}(\%)$ \\
\hline R. rickettsii & $7(100)$ & $2(28.6)$ & $2(28.6)$ & $0(0)$ & $0(0)$ & $1(14.3)$ \\
\hline R. typhi & $1(20)$ & $5(100)$ & $2(40)$ & $1(20)$ & $1(20)$ & $1(20)$ \\
\hline C. burnetii & $2(11.8)$ & $2(11.8)$ & $17(100)$ & $2(11.8)$ & $1(5.9)$ & $2(11.8)$ \\
\hline B. henselae & $0(0)$ & $1(1.7)$ & $2(3.3)$ & $60(100)$ & $47(78.3)$ & $9(15)$ \\
\hline B. quintana & $0(0)$ & $1(1.8)$ & $3(5.4)$ & $47(83.9)$ & $56(100)$ & $9(16.1)$ \\
\hline E. chaffeensis & $1(2.2)$ & $1(2.2)$ & $2(4.3)$ & 9 (19.6) & 9 (19.6) & $46(100)$ \\
\hline
\end{tabular}


as risk area for murine typhus according to a previous report (Parola et al. 1998). Murine typhus has been considered a neglected rickettsiosis worldwide (Walker 2004a) and available data from Europe (Daniel et al. 2002) and Asia (Tay et al. 2003) showed higher rates than in our study. Our results do not support the concept of risk area for $R$. typhi infection in this Brazilian region.

C. burnetii infection has been reported in serosurveys of more than 30 years ago (Ribeiro-Neto et al. 1964, Riemann et al. 1974, 1975) but since then, no information of such infection has been available from Brazil. Q fever has been reported Southern (Moreira et al. 1989) and Northern Brazil (Tran et al. 2002) but for inexplicable reasons little attention has been paid to it, not withstanding the fact that it is supposed to be a worldwide zoonosis presents everywhere (Casolin 1999, CDC 2004). The findings here reported along with the recent report of a human case-series (Costa 2004) demand the inclusion of Q fever among the causative agents of human infections in this region.

Human serosurveys for Bartonella spp. infections are not available in Brazil and our data indicates a high seroprevalence rate in the Piau county. Even when using higher cutoff values or "without multiple/cross-reactivity" seropositivity the seroprevalence remained expressive. Furthermore, higher seroprevalence rates for Bartonella spp. infections have been observed throughout the world (Cimolai et al. 2000, McGill et al. 2001, Tea et al. 2003). Recent evidences of tick-borne transmission for these agents have been published (Chang et al. 2001) and together with their very high frequency among cattle and other domestic animals, enable the possibility of human contact with these agents.

Missing information regarding E. chaffeensis infections seems to the rule in Brazil where the first suspected human cases were just recently published by Calic et al. (2004). Additional human cases were also described thereafter (Costa 2004) but the only previously published serosurvey carried out in Brazil on E. chaffeensis infection found null seroprevalence among humans but not in dogs from that very same region (Galvão et al. 2002). As observed for Bartonella spp. even when using higher cutoffs or without-multiple/cross reactivity seropositivity, expressive numbers of people were positive for $E$. chaffeensis. The rate found here sounds high but was similar to the rate found among 726 febrile patients without acute rickettsial infection from the city of Juiz de Fora (Costa 2004), and also to others reported elsewhere (Paddock \& Childs 2003). In one of the few serologic surveys in South America, Ripoll et al. (1999) found 14\% of positivity in Argentina but rates have ranged from 2 to $20 \%$ throughout the world (Paddock \& Childs 2003). Ehrlichia species particularly E. canis have been recently isolated from Brazilian dogs (Machado 2004) indicating the presence of bacteria belonging to this genus in Brazil. Despite the fact that $E$. chaffeensis is yet to be isolated in Brazil, it may be hypothesized that $E$. chaffeensis or closely related species could be promoting antigenic exposure generating anti-Ehrlichia spp. antibodies irrespective of the involved species.
Ehrlichia species share antigenic identities with Escherichia coli grosEL (Sumner et al. 1993) and this could generate cross-reactive antibodies to E. chaffeensis. Although such cross-reactivity has never been considered in serosurveys, a weak serologic cross-reactivity has already been demonstrated in serologic tests (Unver et al. 2001). Since poor sanitation is the rule in Piau county this might be associated with widespread coliform overexposure resulting in antibody response to $E$. coli cross-reactive to Ehrlichia spp.

The Rickettsia spp. and Coxiella spp. antigenic substrates used in this study derived from yolk sac hens' egg but Bartonella and Ehrlichia spp. antigens were obtained from eucaryotic cells culture. The presence of antinuclear antibodies (ANA) reactive to eucaryotic cell DNA might promote unspecific fluorescence and falsely increase the seroprevalence rates for these last agents. Low titers ANA can be occasionally detected in normal persons but its frequency is supposedly low although agrotoxic exposure has been associated with increased occurrence of ANA (Rosemberg et al. 1999). The use of agrotoxics in the Piau county is allegedly low and the rates of naturally occurring ANA is supposedly low everywhere so this could not be an explanation by itself for the gap of seroprevalence rates observed for Rickettsia and Coxiella (low) as compared with those for Bartonella and Ehrlichia (high).

Age over 40 years old was associated with seropositivity for some but not all tested agents. There are divergent reports in the literature on older age as risk factor for some rickettsial infections with no consensus on this issue. Increased prevalence in children has been suggested in some studies of $R$. rickettsii infection (Anstey et al. 1997, Galvão et al. 2002) but the opposite has also been reported (Lemos et al. 1994, 2001). Older age however has been more often associated with increased rickettsial seropositivity regardless the involved species (Fan et al. 1987) and it seems reasonable to believe that the longer the life the higher the possibility of antigenic exposure to such agents.

Places of residence, slaughtering, milking, cattle contact and horse ownership were not associated with more seropositivity. $R$. rickettsii however showed an unexpected result since was less frequent among individuals with rural professions. E. chaffeensis moreover was more frequently associated with rural residence compatible with more frequent tick exposure. No clear-cut between rural and urban area and rural and non-rural professions in the Piau county exists and this could explain some discrepancies since many people superpose domestic and recreational tasks that facilitate closer animal and tick contact irrespective of their profession and residence place. Some formerly considered risk factors for infections like $C$. burnetii, are no longer thought as exclusive sources for contamination reinforcing the multiple ways of transmission for that particular agent (Pinsky et al. 1991). In this sense, epidemiological investigation in a recent $Q$ fever outbreak in French Guiana found an urban rather than rural pattern of infection distribution (Tran et al. 2002) reinforcing this new paradigm. 
Multiple/cross reactivity was detected in this study and such phenomenon has been frequently observed in serological studies of rickettsial diseases, and usually interpreted as cross-reactivity (Hechemy et al. 1989). Multiple reactivity would represent more than one infection in the same individual, which is a well-known phenomenon in rickettsial infections once several of such agents share identical ways of transmission. (Carpenter et al. 1999). Cross-reactivity would be a result of antigenic determinant similarities between the several rickettsial and non-rickettsial agents, usually suspected by detection of lower antibody titers. The differentiation between multiple-reactivity and cross-reactivity however is difficult and cannot be done without cumbersome cross-absorption tests (Hechemy et al. 1983) and it's also important to remember that both pathogenic and non-pathogenic rickettsial agents can be responsible for the anti-rickettsial antibodies repertoire assembly (Raoult \& Roux 1997). Extensive multiple/cross-reactivity between phase I and phase II $C$. burnetii and between $B$. henselae and $B$. quintana was particularly observed, possibly resulting from antigenic similarities between them (La Scola \& Raoult 1996). The same phenomenon was observed between Bartonella spp. and E. chaffeensis in this study and such aspect has already been reported previously (McGill et al. 1998).

Despite the fact that multiple/cross-reactivity observed in this study did not change dramatically the seroprevalence rates, such findings should reinforce the need of testing not just one but as many as possible rickettsial antigenic matrices while checking any particular rickettsial seroposivity rate for epidemiological purposes.

The used method for antibody testing in this study (IFA) has the same limitations of other serologic methods added to the subjectivity of the viewer but even though it has been considered the standard for serosurveys of rickettsial infections (Anstey et al. 1997, Ripoll et al. 1999). The concomitant testing with another method, especially Western blotting (Carpenter et al. 1999, Unver et al. 2001, Galvão et al. 2002) could overcome some consequent pitfalls of studies like this but from the practical standpoint the majority of published studies have not been testing more than one method simultaneously (Lemos et al. 1994, 2001, Galvão 2004).

In conclusion, very little is known about rickettsial diseases other than $R$. rickettsii infection in Brazil e.g., the involved species, prevalence, incidence, geographic pattern, vectors, hosts, and the existence of human cases.

The data here presented despite their methodological limitations show evidence of different rickettsial infections in the studied population making it important to have them included in the differential diagnosis of the infectious syndromes occurring in this region and probably in other parts of the country with similar conditions. Prospective serologic studies and reliable diagnostic methods should be set in the future to clear these queries.

\section{ACKNOWLEDGMENTS}

To Drs Gregory Dash, James Olson, James Childs, and Russell Regnery from the Viral and Rickettsial branch of CDC Atlanta, US for providing the rickettsial antigens and to Leatrice
Joyce Schubert de Castro, and Eunice Dantas, Health Officials of Piau county.

\section{REFERENCES}

Anstey NM, Tissot-Dupont H, Hahn CG, Mwaikambo ED, McDonald MI, Raoult D, Sexton DJ 1997. Seroepidemiology of Rickettsia typhi, spotted fever group rickettsiae, and Coxiella burnetii infection in pregnant women from urban Tanzania. Am J Trop Med Hyg 57: 187-189.

Calic SB, Galvão MAM, Bacellar F, Rocha CMBM, Mafra CL, Leite RC, Walker DH 2004. Human ehrlichiosis in Brazil: first suspected cases. Braz J Infect Dis 8: 259-262.

Carpenter CF, Gandhi TK, Kong LK, Corey GR, Chen SM, Walker DH, Dumler JS, Breitschwerdt E, Hegarty B, Sexton DJ 1999. The incidence of ehrlichial and rickettsial infection in patients with unexplained fever and recent history of tick bite in central North Carolina. J Infect Dis 180: 900-903.

Casolin A 1999. Q fever in New South Wales department of agriculture workers. J Occup Environ Med 41: 273-278.

CDC-Centers for Disease Control and Prevention 2004. Viral and rickettsial zoonoses branch - Q fever. Available at http:/ /www.cdc.gov/ncidod/dvrd/qfever/index.htm. Accessed May 5.

Chang CC, Chomel BB, Kasten RW, Romano V, Tietze N 2001. Molecular evidence of Bartonella sp in questing adult $I x$ odes pacificus ticks in California. J Clin Microbiol 39: 12211226.

Cimolai N, Benoit L, Hill A, Lyons C 2000. Bartonella henselae infection in British Columbia: evidence for an endemic disease among humans. Can J Microbiol 46: 908-912.

Costa PSG 2004. Evidências Sorológicas de Infecções por Rickettsia rickettsii, Rickettsia typhi, Coxiella burnetii, Bartonella quintana, Bartonella henselae e Ehrlichia chaffeensis em Indivíduos Sadios e Pacientes Febris com e sem AIDS da Região de Juiz de Fora, Minas Gerais, PhD thesis, Belo Horizonte, Minas Gerais.

Costa PSG, Brigatte ME, Almeida EP, Valle LMC 2002. Atypical fulminant Rickettsia rickettsii infection (Brazilian spotted fever) presenting as septic shock and adult respiratory distress syndrome. Braz J Infect Dis 6: 91-96.

da Silva LJ, Papaiordaou MO 2001. Tifo murino: relato de caso e revisão da literatura. Rev Soc Bras Med Trop 34 (Supl. ): 403.

Daniel SA, Manika K, Arvanitidou A, Antoniadis A 2002. Prevalence of Rickettsia conorii and Rickettsia typhi infections in the population of northern Greece. Am J Trop Med Hyg 66: 76-79.

Del Guercio VM, Rocha MM, Melles HB, de Lima VC, Pignatti MG 1997. Febre maculosa no município de Pedreira, SP, Brasil. Inquérito sorológico. Rev Soc Bras Med Trop 30: 4752.

Fan MY, Walker DH, Liu QH, Li H, Bai HC, Wang JG, Lenz B, Cai H 1987. Rickettsial and serologic evidence for prevalent spotted fever rickettsiosis in inner Mongolia. Am J Trop Med Hyg 36: 615-620.

Galvão MAM 1996. Febre Maculosa em Minas Gerais: Um Estudo sobre a Distribuição da Doença no Estado e seu Comportamento em Área de Foco Periurbano. PhD thesis, Belo Horizonte, Minas Gerais. 
Galvão MAM 2004. Diagnósticos e inquéritos sorológicos para riquetsioses do gênero Rickettsia no Brasil. Rev Bras Parasitol Vet 13 (Supl. 1): 188-189.

Galvão MAM, Calic SB, Chamone CB, Mafra CL, Cesarino Filho G, Olano JP, Walker DW 2003. Spotted fever rickettsiosis in Coronel Fabriciano, Minas Gerais state. Rev Soc Bras Med Trop 36: 479-481.

Galvão MAM, Lamounier JA, Bonomo E, Tropia MS, Rezende EG, Calic SB, Cahmone CB, Machado MC, Otoni MEA, Leite RC, Caram C, Mafra CL, Walker DH 2002. Rickettsioses emergentes e reemergentes numa região endêmica do estado de Minas Gerais, Brasil. Cad Saúde Pública 18: 1593-1597.

Hallack KA, Cunha RMC, Roland RK, Hallack Neto AE, Gollner AM 1996. Ocorrência de casos de febre maculosa na zona da mata mineira. In IX Congresso Brasileiro de Infectologia, Recife, Resumo.

Hechemy KE, Anacker RL, Carlo NL, Fox JA, Gaafar HA 1983. Absorption of Rickettsia rickettsii antibodies by Rickettsia rickettsii antigens in four diagnostic tests. J Clin Microbiol 17: 445-449

Hechemy KE, Raoult D, Fox J, Han Y, Elliott LB, Rawlings J 1989. Cross-reaction of immune sera from patients with rickettsial diseases. J Med Microbiol 29: 199-202.

La Scola B, Raoult D 1996. Serological cross-reactions between Bartonella quintana, Bartonella henselae, and Coxiella burnetii. J Clin Microbiol 34: 2270-2274.

Lemos ER, Alvarenga FB, Cintra ML, Ramos MC, Paddock CD, Ferebee TL, Zaki SR, Ferreira FC, Ravagnani RC, Machado RD, Guimarães MA, Coura JR 2001. Spotted fever in Brazil: a seroepidemiological study and description of clinical cases in an endemic area in the state of São Paulo. Am J Trop Med Hyg 65: 329-334.

Lemos ER, Machado RD, Coura JR 1994. Rocky Mountain spotted fever in an endemic area in Minas Gerais, Brazil. Mem Inst Oswaldo Cruz 89: 497-501.

Machado RZ 2004. Erliquiose canina. Rev Bras Parasitol Vet 13 (Supl. 1): 53-7.

McGill SL, Regnery RL, Karem KL 1998. Characterization of human immunoglobulin (Ig) isotype and $\mathrm{IgG}$ subclass response to Bartonella henselae infection. Infec Immun 66: 5915-5920.

McGill SL, Wesslen L, Hjelm E, Holmberg M, Rolf C, Friman G 2001. Serological and epidemiological analysis of the prevalence of Bartonella spp. antibodies in Swedish elite orienteers 1992-93. Scand J Infect Dis 33: 423-428.

Moreira RES, Caffarene RM, Perez G, Saldias SS, Monteiro M 1989. Fiebre Q en Uruguay. Rev Inst Med Trop São Paulo 29: 168-173.

Oliveira RP, Galvão MAM, Mafra CL, Chamone CB, Calic SB, Silva SU, Walker DH 2002. Rickettsia felis in Ctenocephalides spp. fleas, Brazil. Emerg Infect Dis 8: 317-319.

Paddock CD, Childs JE 2003. Ehrlichia chaffeensis: a prototypical emerging pathogen. Clin Microbiol Rev 16: 37-64.

Parola P, Raoult D 2001. Ticks and tick-borne diseases in humans: An emerging infectious threat. Clin Infect Dis 32: 897-928.
Parola P, Vogelaers D, Roure C, Janbon F, Raoult D 1998. Murine typhus in travelers returning from Indonesia. Emerg Infect Dis 4: 677-680.

Philip RN, Casper EA, Ormsbee RA, Peacock MG, Burgdorfer W 1976. Microimmunofluorescence test for the serological study of Rocky Mountain spotted fever and typhus. J Clin Microbiol 3: 51-61.

Pinsky RL, Fishbein DB, Greene CR, Gensheimer KF 1991. An outbreak of cat-associated Q fever in the United States. J Infect Dis 164: 202-204.

Raoult D, Roux V 1997. Rickettsioses as paradigms of new or emerging infectious diseases. Clin Microbiol Dis 10: 694719.

Ribeiro-Neto A, Nikitin T, Ribeiro IF 1964. Estudo sobre a febre Q em São Paulo. III Prevalência em ordenhadores e tratadores de bovinos. Rev Inst Med Trop São Paulo 6: 255257.

Riemann HP, Brant PC, Behymer DE, Franti CE 1975. Toxoplasma gondii and Coxiella burnetii antibodies among Brazilian slaughterhouse employees. Am J Epidemiol 102: 38693.

Riemann HP, Brant PC, Franti CE, Reis R, Buchanan AM, Stormont C, Behymer D 1974. Antibodies to Toxoplasma gondii and Coxiella burnetii among students and other personnel in veterinary colleges in California and Brazil. Am J Epidemiol 100: 197-208.

Ripoll CM, Remondegui CE, Ordonez G, Arazamendi R, Fusaro H, Hyman MJ, Paddock CD, Zaki SR, Olson JG, SantosBush CA 1999. Evidence of rickettsial spotted fever and ehrlichial infections in a subtropical territory of Jujuy, Argentina. Am J Trop Med Hyg 61: 350-354.

Rosenberg AM, Semchuk KM, McDuffie HH, Ledingham DL, Cordeiro DM, Cessna AJ, Irvine DG, Senthilselvan A, Dosman JA. 1999. Prevalence of antinuclear antibodies in a rural population. J Toxicol Environ Health A 57: 225-236.

Rozental T, Bustamante MC, Amorim M, Serra-Freire NM, Lemos ER 2002 Evidence of spotted fever group rickettsiae in state of Rio de Janeiro, Brazil. Rev Inst Med Trop São Paulo 44: 155-158.

Silveira JCB, Maestrini AA 1985. Tifo murino: a propósito de um caso. Annais Fac Med Univ Fed Minas Gerais 34: 103106.

Sumner JW, Sims KG, Jones DC, Anderson BE 1993. Ehrlichia chaffeensis expresses an immunoreactive protein homologous to Escherichia coli GroEL protein. Infect Immun 61: 3536-3539.

Tay ST, Kamalanathan M, Rohani MY 2003. Antibody prevalence of Orientia tsutsugamushi, Rickettsia typhi and TT118 spotted fever group rickettsiae among Malaysian blood donors and febrile patients in the urban areas. Southeast Asian J Trop Med Public 34: 165-170.

Tea A, Alexiou-Daniel S, Arvanitidou M, Diza E, Antoniadis A 2003. Occurrence of Bartonella henselae and Bartonella quintana in a healthy Greek population. Am J Trop Med Hyg 68: 554-556.

Tran A, Gardon J, Weber S, Polidori L 2002. Mapping disease incidence in suburban areas using remotely sensed data. $\mathrm{Am}$ J Epidemiol 156: 662-666. 
Travassos J, Rodrigues PM, Carrijo LN 1949. Tifo murino em São Paulo; identificação da Rickettsia mooseri isolada de um caso humano Mem Inst Butantam 21: 77-106.

Unver A, Felek S, Paddock CD, Zhi N, Horowitz HW, Wormser GP, Cullman LC, Rikihisa Y 2001. Western blot analysis of sera reactive to human monocytic ehrlichiosis and human granulocytic ehrlichiosis agents. J Clin Microbiol. 39: 39823986 .

Walker DH 2004a. Clinical, epidemiologic, and control perspec- tives of rickettsioses and ehrlichiosis in the Americas. Conference. I Simposio Latino-Americano de Rickettsioses (Anais - Suplemento).

Walker DH 2004b. Ricketts creates rickettsiology, the study of vector-borne obligate intracellular bacteria. J Infect Dis 189: 938-55.

WHO-World health organization 1993. Global surveillance of rickettsial diseases: memorandum from a WHO meeting. Bull WHO 71: 293-296. 